\title{
Chapter 7 \\ Bird Collisions in a Railway Crossing a Wetland of International Importance (Sado Estuary, Portugal)
}

\section{Carlos Godinho, João T. Marques, Pedro Salgueiro, Luísa Catarino, Cândida Osório de Castro, António Mira and Pedro Beja}

\begin{abstract}
Many studies have evaluated bird mortality in relation to roads and other human structures, but little is known about the potential impacts of railways. In particular, it is uncertain whether railways are an important mortality source when crossing wetlands heavily used by aquatic birds. Here we analyze bird collisions in a railway that crosses the Nature Reserve of the Sado Estuary (Portugal) over an annual cycle, documenting bird mortality and the flight behaviour of aquatic birds in relation to a bowstring bridge. During monthly surveys conducted on $16.3 \mathrm{~km}$ of railway, we found 5.8 dead birds $/ \mathrm{km} / 10$ survey days in the section crossing wetland habitats $(6.3 \mathrm{~km})$, while $<0.5$ dead birds $/ \mathrm{km} / 10$ survey days were found in two sections crossing only forested habitats. Most birds recorded were small songbirds (Passeriformes), while there was only a small number of aquatic birds (common moorhen, mallard, flamingo, great cormorant, gulls) and other non-passerines associated with wetlands (white stork). During nearly $400 \mathrm{~h}$ of observations, we
\end{abstract}

C. Godinho $(\bowtie) \cdot$ L. Catarino

LabOr - Laboratório de Ornitologia, ICAAM - Instituto de Ciências Agrárias e Ambientais Mediterrânicas, Universidade de Évora, Mitra, 7002-554 Évora, Portugal

e-mail: capg@uevora.pt

J.T. Marques · P. Salgueiro · A. Mira

Unidade de Biologia da Conservação, Departamento de Biologia, Universidade de Évora, Mitra, 7002-554 Évora, Portugal

J.T. Marques · P. Salgueiro · A. Mira

CIBIO/InBIO, Centro de Investigação em Biodiversidade e Recursos Genéticos,

Universidade de Évora, Pólo de Évora, Casa do Cordovil $2^{\circ}$ Andar, 7000-890 Évora, Portugal

C.O. de Castro

Direção de Engenharia e Ambiente. Infraestruturas de Portugal, Campus do Pragal—Ed. 1, Praça da Portagem, 2801-013 Almada, Portugal

P. Beja

CIBIO/InBIO, Centro de Investigação em Biodiversidade e Recursos Genéticos,

Universidade do Porto, Campus Agrário de Vairão, Rua Padre Armando Quintas, 4485-661

Vairão, Portugal

P. Beja

CEABN/InBIO, Centro de Ecologia Aplicada "Professor Baeta Neves", Instituto Superior de Agronomia, Universidade de Lisboa, Tapada da Ajuda, 1349-017 Lisboa, Portugal

(C) The Author(s) 2017

L. Borda-de-Água et al. (eds.), Railway Ecology,

DOI 10.1007/978-3-319-57496-7_7 
recorded 27,000 movements of aquatic birds across the Sado bridge, particularly in autumn and winter. However, only $<1 \%$ of movements were within the area of collision risk with trains, while about $91 \%$ were above the collision risk area, and $8 \%$ were below the bridge. Overall, our case study suggests that bird collisions may be far more numerous in railways crossing wetland habitats than elsewhere, although the risk to aquatic birds may be relatively low. Information from additional study systems would be required to evaluate whether our conclusions apply to other wetlands and railway lines.

Keywords Anthropogenic mortality - Aquatic birds - Collision risk • Environmental impact • Wetlands · Wildlife mortality

\section{Introduction}

Collision with human structures and vehicles is an important source of wild bird mortality, killing hundreds of millions of birds each year (Loss et al. 2015). Although the population-level consequences of such mortality are poorly known (but see, e.g., Carrete et al. 2009; Borda-de-Água et al. 2014), it is generally recognized under the precautionary principle that efforts should be made to reduce the number of birds killed each year as much as possible (Loss et al. 2015). Information is thus needed on the bird species most vulnerable to collisions, and on the environmental and species-specific factors affecting such vulnerability (Barrios and Rodríguez 2004; Santos et al. 2016), which are essential for developing management guidelines aimed at reducing collision risk (Barrientos et al. 2011; May et al. 2015).

To collect baseline information for mitigating impacts, bird collision risk has been the subject of intensive research over the past two decades (Loss et al. 2015), with many studies documenting bird mortality and its correlates in relation to roads (Santos et al. 2016), wind farms (Barrios and Rodríguez 2004; Drewitt and Langston 2006), power lines (Barrientos et al. 2011, 2012), and buildings (Loss et al. 2015). Surprisingly, however, very few studies have analyzed bird collision in relation to railways, although these linear infrastructures extend over tens of thousands of kilometers across the world (see Chap. 2). Railways present a number of risks to birds from potential collisions with circulating trains, but there are also risks regarding collision with catenary wires, electrocution, and barotrauma by the train movement (Dorsey et al. 2015, and see Chap. 2). The few studies addressing these problems reported that birds can account for over $50 \%$ of the vertebrates killed in railways (SCV 1996; van der Grift and Kuijsters 1998), and that collisions may often involve species of conservation concern such as owls and birds of prey (Peña and Llama 1997; SCV 1996; Schaub et al. 2010). For some of these species, railway-related mortality may represent a considerable proportion of the overall mortality (van der Grift and Kuijsters 1998; Schaub et al. 2010), and thus may be a risk worth considering when designing or managing railways. However, the few studies conducted so far have covered just a very limited range of species and environmental conditions, making it difficult to draw generalizations (see Chap. 2). 
Here we provide a case study on bird collisions in a railway that crosses a wetland of international importance, the Sado Estuary (Portugal), which is a RAMSAR site and a Special Protection Area for birds classified under the European Union Directive 79/409/EEC. Especially from autumn to mid-spring, this wetland is home to thousands of waders, wildfowl, flamingos Phoenicopterus roseus, and other aquatic birds, which use a diversity of wet habitats including open water, mud flats, rice fields, and salt pans (Lourenço et al. 2009; Alves et al. 2011). These birds were expected to cross the railway area on a daily basis, particularly the bridge crossing the Sado River, due to movements from roosts to feeding areas, and among feeding areas (e.g., Dias et al. 2006). Therefore, it was feared that they were exposed to a high risk of collision, with the possibility of mass mortality events occurring due to the collision of large flocks with bridge structures and circulating trains. Our study was designed to clarify this issue, aiming at: (1) quantifying bird mortality patterns due to collisions associated with the presence of the railway; (2) characterizing the movements of wetland birds crossing the railway bridge along the circadian and the annual cycles; and (3) estimating the seriousness of the risk of wetland bird mortality associated with this railway, as well as which bird species are most at risk. To the best of our knowledge, this is the first published study documenting the impacts of railways on wetland bird mortality.

\section{Methods}

The study was carried out in Portugal, focusing on the "Variante de Alcácer" railway, whose construction started in February 2007, with train circulation beginning in December 2010 (Figs. 7.1 and 7.2). This is a single-track electrified railway extending over $29 \mathrm{~km}$, that is part of the network connecting Lisbon to the south of the country. It crosses the Natural Reserve of the Sado Estuary (Portugal) in a section of about $2.6 \mathrm{~km}\left(38^{\circ} 24^{\prime} \mathrm{N}, 8^{\circ} 36^{\prime} \mathrm{W}\right)$, most of which is occupied by wetland habitats including the Sado River, rice fields and salt pans $(1.6 \mathrm{~km})$, while the rest is dominated by cork oak Quercus suber and stone pine Pinus pinea woodlands. The crossing is made through a bowstring bridge built between 2007 and 2010, with a length of $2735 \mathrm{~m}$ and three $160 \mathrm{~m}$ high arcs (Fig. 7.2). Another viaduct of this railway (about $0.8 \mathrm{~km}$ ) crosses a small wetland outside the Natural Reserve, which corresponds to the São Martinho stream and the adjacent rice fields (Fig. 7.2). During the period of observations conducted over one year (see below), the bridge was crossed by $26 \pm 4$ [SD] trains/day. The train speed ranged from $44 \mathrm{~km} / \mathrm{h}$ (charcoal trains) to $170-200 \mathrm{~km} / \mathrm{h}$ (passenger trains).

Bird mortality due to collisions with trains and railway structures was estimated at three sections of this railway, with a total length of $16.3 \mathrm{~km}$. One of these sections (Section 1: $6.3 \mathrm{~km})$ included the sectors crossing the Sado $(2.6 \mathrm{~km})$ and São Martinho $(0.8 \mathrm{~km})$ wetlands, while the rest $(2.9 \mathrm{~km})$ crossed forested habitats. The other two sections (Section 2: $5.8 \mathrm{~km}$; Section 3: $4.2 \mathrm{~km}$ ) crossed only forested habitats, and they were used as controls to estimate how the presence of wetlands affected bird collision rates. The railway tracks and the surrounding areas were thoroughly surveyed for vertebrate corpses in the three sections, between 


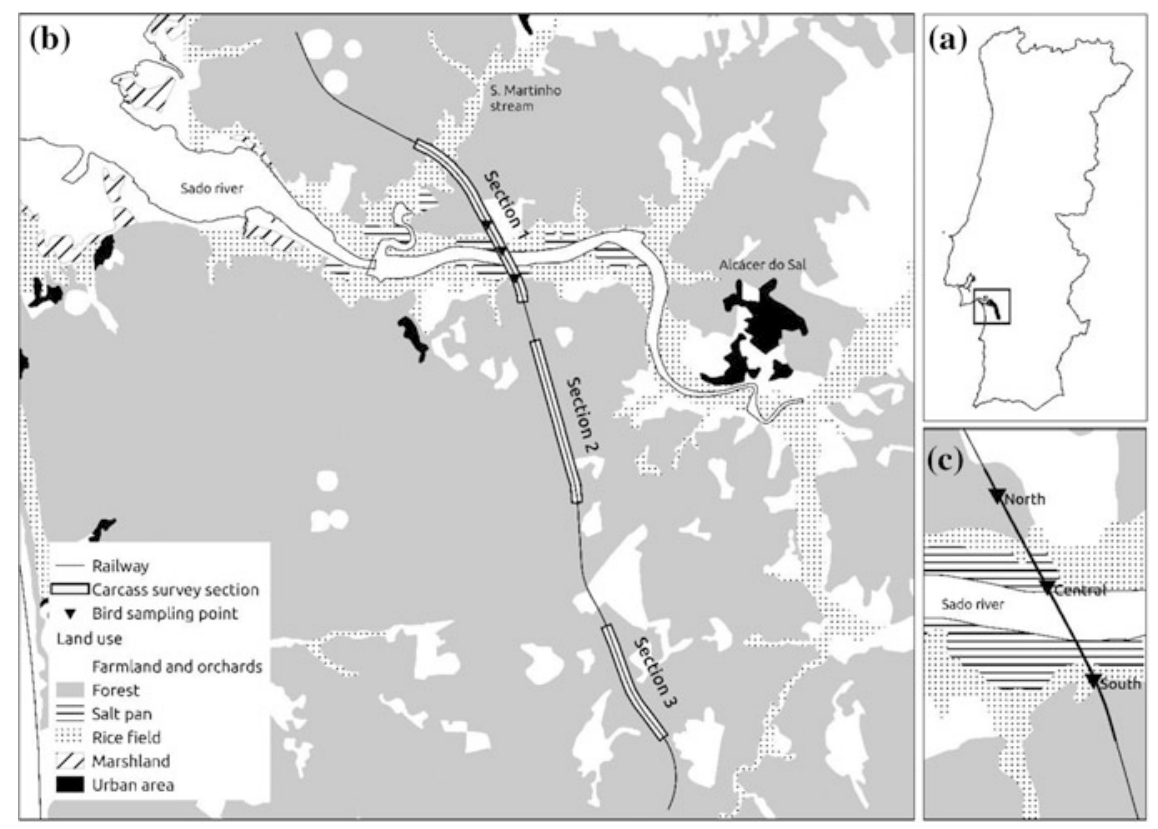

Fig. 7.1 a Location of the Sado Estuary in Portugal, $\mathbf{b}$ map of the study area showing the location of the three sections surveyed for bird mortality in the Variante de Alcácer" railway line, and c detail of the section 1 crossing the Sado River, with the location of the three bird counting points

November 2012 and October 2013. In section 1, surveys were conducted once a each month, and on two consecutive days per month. In sections 2 and 3, surveys were conducted in the same months as Section 1, but they were carried out in a single day each month. For safety reasons, surveys were conducted only when accompanied by staff of the railway company and following all safety procedures. Each bird corpse located during surveys was identified to the lowest possible taxonomic level and its position was recorded with a GPS receiver.

To evaluate bird movements across the Sado bridge, observations were made within 500-m buffers at three sampling points set $1 \mathrm{~km}$ apart along the bridge, and covering all deck (Figs. 7.1 and 7.2). The points were set to cover the main habitats available in the area: North - forested areas; Central — river and wetland habitats; South - forest and wetland habitats (Fig. 7.2). Twenty-two survey sessions took place between November 2012 and September 2013 by three observers simultaneously. The number of birds crossing the railway were counted during the day in two 6-hours sessions per month (i.e., $\approx 400 \mathrm{~h}$ of observation homogeneously distributed during the study period), to cover the tidal cycle. Observers rotated between observation points every $3 \mathrm{~h}$ to avoid hour-related biases. Species, number of individuals, hour, flight direction and height (based on structural elements of the bridge: (deck, electric cables and bridge arcs) were recorded for each crossing. Particular care was taken to estimate the number of birds crossing at the train collision risk zone, corresponding to the area between the deck and the catenary lines. 
Fig. 7.2 Photographs illustrating aspects of the study area. Upper panel railway crossing rice fields (São Martinho stream); middle panel bowstring railway bridge crossing the Sado River; lower panel flock of flamingos flying close to the Sado railway bridge
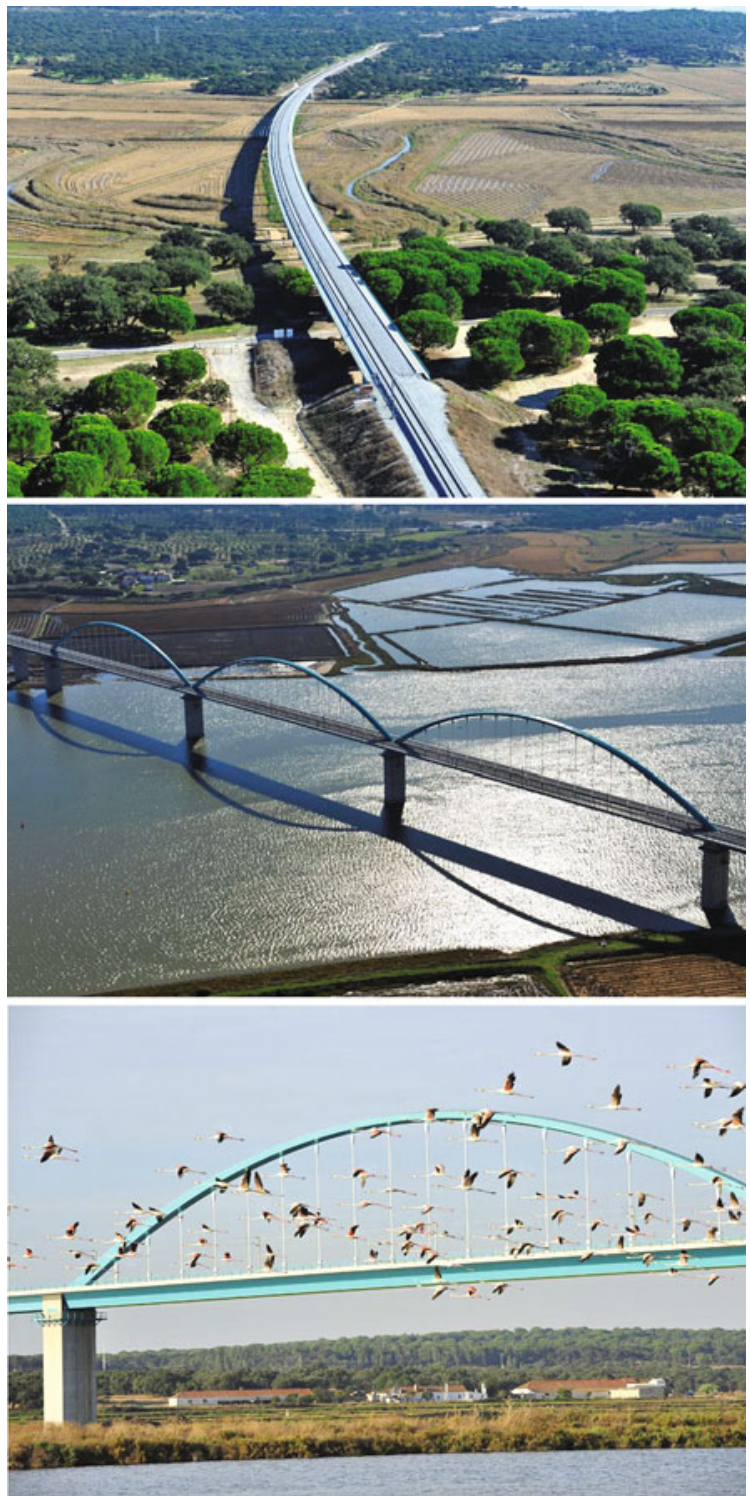

\section{Results}

\section{Bird Mortality}

Overall, we found 124 vertebrate corpses during mortality surveys, most of which (75.8\%) were birds, although there were also a few amphibians (8.9\%), reptiles 
(3.2\%), mammals (8.9\%), and unidentified vertebrates (3.2\%) (Table 7.1). Most birds were passerines (Passeriformes), which accounted for 15 of the 25 species identified, and $67.9 \%$ of 53 individuals identified to species level. White wagtails (Motacilla alba) accounted for about $35 \%$ of the individuals identified, while for 18 species we found only a single individual. Only eight individuals of strictly aquatic species were identified, including two common moorhens (Gallinula chloropus), and one each of mallard (Anas plathyrhynchos), flamingo, great cormorant (Phalacrocorax carbo) and lesser black-backed gull (Larus fuscus). To these should be added five white storks (Ciconia ciconia), which are frequently found in flooded rice fields in the area.

Table 7.1 Summary results of vertebrate mortality detected in the "Variante de Alcácer" railway (southern Portugal), between November 2012 and October 2013

\begin{tabular}{|c|c|c|c|c|c|c|}
\hline \multirow[t]{3}{*}{ Species } & \multirow{2}{*}{\multicolumn{2}{|c|}{\begin{tabular}{|l|} 
Section 1 \\
$\begin{array}{l}\text { Wetland/Forest } \\
(6.3 \mathrm{~km})\end{array}$ \\
\end{tabular}}} & \multirow{2}{*}{\multicolumn{2}{|c|}{\begin{tabular}{|l|} 
Section 2 \\
Forest $(5.8 \mathrm{~km})$
\end{tabular}}} & \multirow{2}{*}{\multicolumn{2}{|c|}{\begin{tabular}{|l|} 
Section 3 \\
Forest $(4.2 \mathrm{~km})$ \\
\end{tabular}}} \\
\hline & & & & & & \\
\hline & $\mathrm{N}$ & $\mathrm{N} / \mathrm{km} / 10$ days & $\mathrm{N}$ & $\mathrm{N} / \mathrm{km} / 10$ days & $\mathrm{N}$ & $\mathrm{N} / \mathrm{km} / 10$ days \\
\hline Amphibians & 6 & 0.40 & 2 & 0.29 & 3 & 0.60 \\
\hline Common toad Bufo bufo & - & - & 1 & 0.14 & - & - \\
\hline Natterjack toad Bufo calamita & - & - & - & - & 2 & 0.40 \\
\hline $\begin{array}{l}\text { Common/Natterjack toad Bufo } \\
\text { bufo/calamita }\end{array}$ & - & - & - & - & 1 & 0.20 \\
\hline Treefrog Hyla sp. & 1 & 0.07 & 1 & 0.14 & - & - \\
\hline Perez's frog Rana perezi & 1 & 0.07 & - & - & - & - \\
\hline $\begin{array}{l}\text { Fire salamander Salamandra } \\
\text { salamandra }\end{array}$ & 1 & 0.07 & - & - & - & - \\
\hline Crested newt Triturus marmoratus & 1 & 0.07 & - & - & - & - \\
\hline Unidentified amphibian & 2 & 0.13 & - & - & - & - \\
\hline Reptiles & 2 & 0.13 & - & - & 2 & 0.40 \\
\hline $\begin{array}{l}\text { Large psammodromus } \\
\text { Psammodromus algirus }\end{array}$ & - & - & - & - & 2 & 0.40 \\
\hline $\begin{array}{l}\text { Montpellier snake Malpolon } \\
\text { monspessulanus }\end{array}$ & 2 & 0.13 & - & - & - & - \\
\hline Birds & 89 & 5.89 & 3 & 0.43 & 2 & 0.40 \\
\hline Mallard Anas plathyrhychos & 1 & 0.07 & - & - & - & - \\
\hline $\begin{array}{l}\text { Greater flamingo Phoenicopterus } \\
\text { roseus }\end{array}$ & 1 & 0.07 & - & - & - & - \\
\hline White stork Ciconia ciconia & 5 & 0.33 & - & - & - & - \\
\hline $\begin{array}{l}\text { Great cormorant Phalacrocorax } \\
\text { carbo }\end{array}$ & 1 & 0.07 & - & - & - & - \\
\hline Cattle egret Bubulcus ibis & 1 & 0.07 & - & - & - & - \\
\hline Moorhen Gallinula chloropus & 2 & 0.13 & - & - & - & - \\
\hline $\begin{array}{l}\text { Lesser black-backed gull Larus } \\
\text { fuscus }\end{array}$ & 1 & 0.07 & - & - & - & - \\
\hline $\begin{array}{l}\text { Rock dove (domestic) Columba } \\
\text { livia }\end{array}$ & 3 & 0.20 & - & - & - & - \\
\hline
\end{tabular}


Table 7.1 (continued)

\begin{tabular}{|c|c|c|c|c|c|c|}
\hline \multirow[t]{3}{*}{ Species } & \multicolumn{2}{|c|}{ Section 1} & \multicolumn{2}{|c|}{ Section 2} & \multicolumn{2}{|c|}{ Section 3} \\
\hline & \multicolumn{2}{|c|}{$\begin{array}{l}\text { Wetland/Forest } \\
(6.3 \mathrm{~km})\end{array}$} & \multicolumn{2}{|c|}{ Forest $(5.8 \mathrm{~km})$} & \multicolumn{2}{|c|}{ Forest $(4.2 \mathrm{~km})$} \\
\hline & $\mathrm{N}$ & $\mathrm{N} / \mathrm{km} / 10$ days & $\mathrm{N}$ & $\mathrm{N} / \mathrm{km} / 10$ days & $\mathrm{N}$ & $\mathrm{N} / \mathrm{km} / 10$ days \\
\hline Tawny owl Strix aluco & 1 & 0.07 & - & - & - & - \\
\hline Little owl Athene noctua & - & - & 1 & 0.14 & - & - \\
\hline Carrion crow Corvus corone & 1 & 0.07 & - & - & - & - \\
\hline Wood lark Lululla arborea & - & - & 1 & 0.14 & - & - \\
\hline Barn swallow Hirundo rustica & 2 & 0.13 & - & - & - & - \\
\hline Blue tit Cyanistes caeruleus & 1 & 0.07 & - & - & - & - \\
\hline $\begin{array}{l}\text { Common chiffchaff Phylloscopus } \\
\text { collybita }\end{array}$ & 1 & 0.07 & - & - & - & - \\
\hline $\begin{array}{l}\text { Reed warbler Acrocephalus } \\
\text { scirpaceus }\end{array}$ & 2 & 0.13 & - & - & - & - \\
\hline Blackcap Sylvia atricapilla & - & - & - & - & 1 & 0.20 \\
\hline $\begin{array}{l}\text { Common redstart Phoenicurus } \\
\text { ochruros }\end{array}$ & 1 & 0.07 & - & - & - & - \\
\hline $\begin{array}{l}\text { European stonechat Saxicola } \\
\text { rubicola }\end{array}$ & 1 & 0.07 & - & - & - & - \\
\hline Song thrush Turdus philomelos & - & - & 1 & 0.14 & - & - \\
\hline Mistle thrush Turdus viscivorus & - & - & - & - & 1 & 0.20 \\
\hline White wagtail Motacilla alba & 19 & 1.26 & - & - & - & - \\
\hline Chaffinch Fringilla coelebs & 1 & 0.07 & - & - & - & - \\
\hline $\begin{array}{l}\text { Greenfinch/goldfinch Chloris } \\
\text { chloris/Carduelis carduelis }\end{array}$ & 1 & 0.07 & - & - & - & - \\
\hline House sparrow Passer domesticus & 2 & 0.13 & - & - & - & - \\
\hline Unidentified Ardeidae & 1 & 0.07 & - & - & - & - \\
\hline Unidentified Columbidae & 3 & 0.20 & - & - & - & - \\
\hline Unidentified aquatic bird & 1 & 0.07 & - & - & - & - \\
\hline $\begin{array}{l}\text { Unidentified songbird } \\
\text { (Passeriforme) }\end{array}$ & 6 & 0.40 & - & - & - & - \\
\hline Unidentified bird & 30 & 1.98 & - & - & - & - \\
\hline Mammals & 8 & 0.53 & 2 & 0.29 & 1 & 0.20 \\
\hline $\begin{array}{l}\text { Kuhl's pipistrelle Pipistrellus } \\
\text { kuhlii }\end{array}$ & - & - & - & - & 1 & 0.20 \\
\hline Wood mouse Apodemus sylvaticus & - & - & 1 & 0.14 & - & - \\
\hline Red fox Vulpes vulpes & 1 & 0.07 & - & - & - & - \\
\hline Stone marten Martes foina & 1 & 0.07 & - & - & - & - \\
\hline Domestic cat Felis catus & 1 & 0.07 & - & - & - & - \\
\hline Domestic sheep Ovis aries & 4 & 0.26 & - & - & - & - \\
\hline Unidentified carnivore & 1 & 0.07 & - & - & - & - \\
\hline Unidentified mammal & - & - & 1 & 0.14 & - & - \\
\hline Unidentified vertebrate & 4 & 0.26 & - & - & - & - \\
\hline Total & 109 & 7.21 & 7 & 1.01 & 8 & 1.59 \\
\hline
\end{tabular}

Results are reported separately for three sections of the railway with different lengths and crossing different habitats. For each section and species/taxa, we provide the total number of individuals detected $(\mathrm{N})$ and the number of individuals detected per $\mathrm{km}$ and per 10 survey days $(\mathrm{N} / \mathrm{km} / 10$ days) 
Most of the birds $(94.6 \%)$ were found in Section 1, where we recorded 5.89 birds $/ \mathrm{km} / 10$ survey days, while in Sections 2 and 3 we recorded 0.43 birds $/ \mathrm{km} / 10$ days and 0.40 birds $/ \mathrm{km} / 10$ days, respectively (Table 7.1 ). Within Section 1 , we found $76.4 \%$ of the birds in the two sectors crossing the Sado River $(n=59)$ and the São Martinho stream $(n=9)$ (Table 7.1). These two sectors were responsible for all mortality of strictly aquatic species, and for $80 \%$ of the white storks killed. Most bird mortality was recorded in the autumn (37.2\%) and winter $(33.0 \%)$, with much lower values in the spring (16.0\%) and summer (13.8\%). The group of aquatic birds and white stork were recorded in each season except winter.

\section{Bridge Crossing by Birds}

We observed a total of about 27,000 birds crossing the bridge during the observation periods, most of which $(82.7 \%)$ were waterfowl and other aquatic birds, and the others were mainly passerines. Overall, most crossings $(76.6 \%)$ were detected in the central section of the bridge, followed by the south $(18.7 \%)$ and north sections $(4.7 \%)$. More than half the crossings were detected in winter (DecemberFebruary), corresponding to 4217 crossings/month (Fig. 7.3). Spring (March-June) was the season with fewer crossings observed, with 571 crossings per month (Fig. 7.3). Less than $1 \%$ of the crossings were made between the deck and the

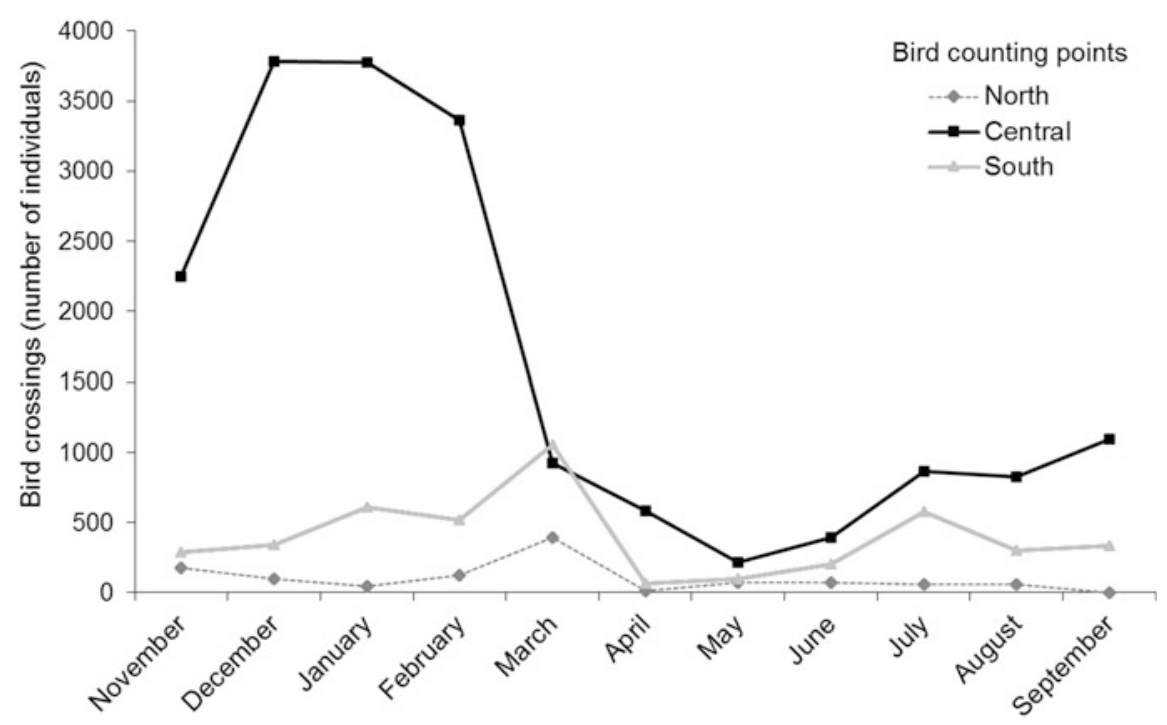

Fig. 7.3 Monthly number of aquatic birds observed crossing the railway bridge over the Sado River, between November 2012 and September 2013. Numbers are presented separately for the three sampling points covering the main habitats available in the area: north (forested areas); central (river and wetland habitats); and south (forest and wetland habitats) 
Table 7.2 Aquatic bird species observed most frequently crossing the railway bridge over the Sado River, indicating the total number of birds crossing and the number of crosses within the train collision risk zone (between the deck and the catenary lines)

\begin{tabular}{l|l|l|l}
\hline \multicolumn{2}{l}{ Species } & $\begin{array}{l}\text { Total } \\
\text { crosses }\end{array}$ & $\begin{array}{l}\text { Collision risk } \\
\text { zone }\end{array}$ \\
\hline $\begin{array}{l}\text { Lesser black-backed } \\
\text { gull }\end{array}$ & Larus fuscus & 8432 & $20(<1 \%)$ \\
\hline Black-headed gull & $\begin{array}{l}\text { Chroirocephalus } \\
\text { ridibundus }\end{array}$ & 7036 & $91(1 \%)$ \\
\hline Great cormorant & Phalacrocorax carbo & 1982 & $10(1 \%)$ \\
\hline Glossy ibis & Plegadis falcinellus & 1596 & $10(<1 \%)$ \\
\hline White stork & Ciconia ciconia & 1380 & $25(2 \%)$ \\
\hline Little egret & Egretta garzetta & 1074 & $17(2 \%)$ \\
\hline Western cattle egret & Bubulcus ibis & 693 & $19(3 \%)$ \\
\hline Mallard & Anas platyrhynchos & 205 & $1(<1 \%)$ \\
\hline Dunlin & Calidris alpina & 99 & $15(15 \%)$ \\
\hline Black stork & Ciconia nigra & 16 & $2(13 \%)$ \\
\hline
\end{tabular}

catenary lines, where there is a risk of collision with trains (Fig. 7.3). Although most birds crossed the bridge above the train collision risk zone (91.3\%), 39.1\% of the crossings were recorded below the top of the bridge arcs (Fig. 7.3).

Most aquatic birds observed crossing the bridge were gulls (lesser black-backed gull and black-headed gull (Chroicocephalus ridibundus), greater flamingos and glossy ibis (Plegadis falcinellus) (Table 7.2). The proportion of crossings within the train collision risk height were low $(\leq 3 \%)$ for most species, with relatively high values $(>10 \%)$ recorded only for dunlin (Calidris alpine) and black stork $(C$. nigra) (Fig. 7.4; Table 7.2). In the case of black storks, however, this value is based on just two individuals observed flying at a low height.

\section{Discussion}

Our results suggest that bird mortality in the "Variante de Alcácer" railway was relatively low during the study period, although there were sharp peaks in the two sectors where it crossed wetland habitats. Nevertheless, there were very few aquatic birds found dead, suggesting that they were not particularly susceptible to collisions with circulating trains or the railway structures. This was in line with the observations of aquatic birds flying across the railway in the area of the bridge over the Sado River, with only a very small proportion of individuals using heights that expose them to collision risk. Overall, we suggest that this railway is unlikely to cause significant mortality to aquatic bird species, although it remains uncertain whether this result can be extrapolated to other wetlands and railway lines.

This study had some limitations and potential shortcomings, but it is unlikely that they have significantly affected our key findings. A potentially important 


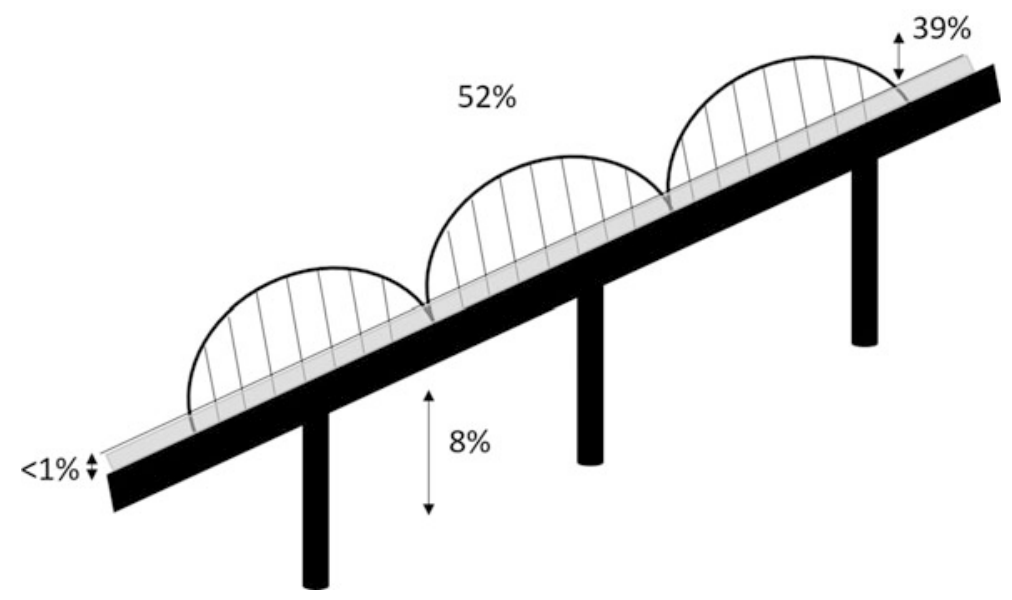

Fig. 7.4 Schematic drawing of the bowstring railway bridge across the Sado River, showing the proportion of bird crossings at various heights during one annual cycle (November 2012September 2013). The grey section indicates the birds flying at the heights of collision risk with circulating trains

problem is that mortality surveys were carried out at monthly intervals and only on one or two days per month, which may influence mortality estimates (Santos et al. 2011, 2015). For instance, an eventual mass mortality event due to a flock colliding with a train might go unnoticed, if it occurs after a monthly survey and corpses decay or are removed until the next survey (Santos et al. 2011). The problem may be particularly serious for small passerines, because their corpses are likely to persist for very short periods in the railway, thereby causing underestimation of the mortality rate (Santos et al. 2011) and making it difficult to precisely estimate the location of mortality hotspots (Santos et al. 2015). However, the main focus of this study was on aquatic birds, which tend to be relatively large and thus less affected by very short persistence times. Furthermore, a collision with a flock of large birds would likely be detected by the train driver and then reported to the safety department. Also, the observation that mortality hotspots were coincident with wetland crossings is unlikely to be due to survey bias, given that the number of bird corpses per $\mathrm{km}$ and survey day detected therein was more than 10 times higher than anywhere else along this railway. This number might be even greater, because some birds colliding with trains on the wetland bridges could be thrown to the surrounding water or other wet habitats, where they would likely decay rapidly or otherwise go unnoticed by observers. Another potential problem is that bird movements across the bridge over the Sado River were also observed for just a few days, and we did not include days with poor visibility conditions (e.g., fog) or night time periods when there may be considerable activity by waders (Lourenço et al. 2008). Therefore, our conclusion that birds were mainly flying outside the collision risk areas should be accepted with care, because it cannot be completely ruled out that more dangerous flight patterns were taken at night or under particular weather conditions. 
Despite these potential problems, our study suggests that the mortality risk for birds was higher in railway sections crossing wetlands than elsewhere, as underlined by the concentration of bird kills in the Sado and, to a lesser extent, the São Martinho wetlands. However, in contrast to expectations, most mortality involved small passerines, particularly white wagtails, while there were only a few aquatic birds killed. This may be a consequence of the high productivity of wetland habitats, which attract large numbers of birds that are then exposed to collision with circulating trains and railway structures during their daily movements. In the Mediterranean region, these wetlands are particularly important in autumn and winter, when they are used by large numbers of passerines from northern latitudes (Finlayson et al. 1992), which may be associated with the higher mortality observed during these seasons. Aquatic birds may be less exposed to collisions because they fly higher than small passerines (see below), which may explain the small number of kills recorded in our study. However, this may vary in relation to ecological conditions and railway characteristics, because apparently larger mortalities of gulls and waterfowl have been found in other study areas (van der Grift and Kuijsters 1998; Heske 2015).

As expected, we found a large number of aquatic birds crossing the bridge over the Sado River, particularly from October to February, and following a path along the river. The birds observed most frequently included a number of waterfowl, waders and other aquatic species, which are abundant both locally and across the estuary (Alves et al. 2011). The flight patterns taken by these birds suggest that they were very rarely at risk of collision with circulating trains or bridge structures. We found that only a very small proportion of crossings $(\approx 1 \%)$ were within the height of collision risk with trains, while most birds $(\approx 52 \%)$ crossed above the bridges' arcs. Actually, the presence of the arcs may have helped deflect birds away from the collision risk area, as we often observed birds avoiding these by changing flight paths. This is in line with observations showing that individual birds and bird flocks change flight paths in response to the presence of anthropogenic structures such as pole barriers (Zuberogoitia et al. 2015).

Overall, our study contributed to clarifying the bird mortality risk due to collisions in railways, adding to just a few previous studies addressing this issue (SCV 1996; Peña and Llama 1997; van der Grift and Kuijsters 1998; Schaub et al. 2010, see also Chap. 2). Our results, together with those previous studies, suggest that the risk associated with railways may be relatively low compared to other anthropogenic sources of mortality (Loss et al. 2015), although differences are difficult to judge precisely, because of the variation in methodological approaches and ecological contexts. Nevertheless, it is worth noting that there were many more collisions where railways crossed wetland habitats, suggesting that the planning of new railways should strive to avoid these habitats as much as possible. Where this is unfeasible or undesirable, monitoring programs should be implemented to evaluate the risks and provide information to design mitigation measures if necessary. Despite the relatively low numbers of dead aquatic birds recorded in our study, we believe that they should not be disregarded in monitoring programs because mortality patterns may depend on local ecological and railway 
characteristics. Overall, we suggest that further empirical studies are necessary on other railways and covering a wider range of ecological conditions, to help draw generalizations that can be useful for landscape planners and environmental managers.

Acknowledgements This study was supported by Infraestruturas de Portugal with the contribution of the Portuguese Science Foundation through the doctoral Grants SFRH/BD/81602/2011 (Carlos Godinho) and SFRH/BD/87177/2012 (Pedro Salgueiro). Carlos Oliveira and José Rebocho (REFER Manutenção) provided invaluable help during the mortality surveys.

\section{References}

Alves, J. A., Dias, M., Rocha, A., Barreto, B., Catry, T., Costa, H., et al. (2011). Monitorização das populações de aves aquáticas dos estuários do Tejo, Sado e Guadiana. Relatório do ano de 2010. Anuário Ornitológico (SPEA), 8, 118-133.

Barrientos, R., Alonso, J. C., Ponce, C., \& Palacin, C. (2011). Meta-analysis of the effectiveness of marked wire in reducing avian collisions with power lines. Conservation Biology, 25, 893-903.

Barrientos, R., Ponce, C., Palacin, C., Martín, C. A., Martín, B., \& Alonso, J. C. (2012). Wire marking results in a small but significant reduction in avian mortality at power lines: A BACI designed study. PLoS ONE, 7, e32569.

Barrios, L., \& Rodríguez, A. (2004). Behavioral and environmental correlates of soaring-bird mortality at on-shore wind turbines. Journal of Applied Ecology, 41, 72-81.

Borda-de-Água, L., Grilo, C., \& Pereira, H. M. (2014). Modeling the impact of road mortality on barn owl (Tyto alba) populations using age-structured models. Ecological Modelling, 276, 29 37.

Carrete, M., Sánchez-Zapata, J. A., Benítez, J. R., Lobón, M., \& Donázar, J. A. (2009). Large scale risk assessment of wind-farms on population viability of a globally endangered long-lived raptor. Biological Conservation, 142, 2954-2961.

Dias, M. P., Granadeiro, J. P., Lecoq, M., Santos, C. D., \& Palmeirim, J. M. (2006). Distance to high-tide roosts constrains the use of foraging areas by dunlins: Implications for the management of estuarine wetlands. Biological Conservation, 131, 446-452.

Dorsey, B., Olsson, M., \& Rew, L. J. (2015). Ecological effects of railways on wildlife. In R. van der Ree, D. J. Smith, \& C. Grilo (Eds.), Handbook of Road Ecology (pp. 219-227). West Sussex: Wiley.

Drewitt, A. L., \& Langston, R. H. (2006). Assessing the impacts of wind farms on birds. Ibis, 148, $29-42$.

Finlayson, C. M., Hollis, G. E., \& Davis, T. J. (1992). Managing Mediterranean Wetlands and Their Birds. IWRB Special Publication 20. Slimbridge: International Wetland Research Bureau.

Heske, E. J. (2015). Blood on the tracks: Track mortality and scavenging rate in urban nature preserves. Urban Naturalist, 4, 1-13.

Loss, S. R., Will, T., \& Marra, P. P. (2015). Direct mortality of birds from anthropogenic causes. Annual Review of Ecology Evolution and Systematics, 46, 99-120.

Lourenço, P. M., Groen, N., Hooijmeijer, J. C. E. W., \& Piersma, T. (2009). The rice fields around the estuaries of the Tejo and Sado are a critical stopover area for the globally near-threatened Black-tailed Godwit Limosa l. limosa: Site description, international importance and conservation proposals. Airo, 19, 19-26.

Lourenço, P. M., Silva, A., Santos, C. D., Miranda, A. C., Granadeiro, J. P., \& Palmeirim, J. M. (2008). The energetic importance of night foraging for waders wintering in a temperate estuary. Acta Oecologica, 34, 122-129. 
May, R., Reitan, O., Bevanger, K., Lorentsen, S. H., \& Nygård, T. (2015). Mitigating wind-turbine induced avian mortality: Sensory, aerodynamic and cognitive constraints and options. Renewable and Sustainable Energy Reviews, 42, 170-181.

Peña, O. L., \& Llama, O. P. (1997). Mortalidad de aves en un tramo de linea de ferrocarril. Grupo Local SEO-Sierra de Guadarrama, Spain. Unpublished report. SEO/BirdLife, Grupo local SEO-Sierra de Guadarrama. Retrieved July 19, 2016, from http://www.actiweb.es/ seosierradeguadarrama/archivo1.pdf

Santos, S. M., Carvalho, F., \& Mira, A. (2011). How long do the dead survive on the road? Carcass persistence probability and implications for road-kill monitoring surveys. PLOS ONE, 6, e25383.

Santos, S. M., Marques, J. T., Lourenço, A., Medinas, D., Barbosa, A. M., Beja, P., et al. (2015). Sampling effects on the identification of roadkill hotspots: Implications for survey design. Journal of Environmental Management, 162, 87-95.

Santos, S. M., Mira, A., Salgueiro, P. A., Costa, P., Medinas, D., \& Beja, P. (2016). Avian trait-mediated vulnerability to road traffic collisions. Biological Conservation, 200, 122-130.

Schaub, M., Aebischer, A., Gimenez, O., Berger, S., \& Arlettaz, R. (2010). Massive immigration balances high anthropogenic mortality in a stable eagle owl population: Lessons for conservation. Biological Conservation, 143, 1911-1918.

S. C. V. (1996). Mortalidad de vertebrados en líneas de ferrocarril. Documentos Técnicos de Conservación SCV 1. Madrid: Sociedad Conservación de Vertebrados.

van der Grift, E. A., \& Kuijsters, H. M. J. (1998). Mitigation measures to reduce habitat fragmentation by railway lines in the Netherlands. In G. L. Evink, P. Garrett, D. Zeigler, \& J. Berry (Eds.), Proceedings of the international conference on wildlife ecology and transportation (pp. 166-170). Tallahassee: Florida Department of Transportation.

Zuberogoitia, I., del Real, J., Torres, J. J., Rodríguez, L., Alonso, M., de Alba, V., et al. (2015). Testing pole barriers as feasible mitigation measure to avoid bird vehicle collisions (BVC). Ecological Engineering, 83, 144-151.

Open Access This chapter is licensed under the terms of the Creative Commons Attribution 4.0 International License (http://creativecommons.org/licenses/by/4.0/), which permits use, sharing, adaptation, distribution and reproduction in any medium or format, as long as you give appropriate credit to the original author(s) and the source, provide a link to the Creative Commons license and indicate if changes were made.

The images or other third party material in this chapter are included in the chapter's Creative Commons license, unless indicated otherwise in a credit line to the material. If material is not included in the chapter's Creative Commons license and your intended use is not permitted by statutory regulation or exceeds the permitted use, you will need to obtain permission directly from the copyright holder.

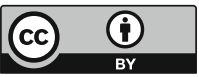

